\title{
Flexural Behavior of Rolled Steel I Beam with Different Stiffener Position
}

\author{
Prabha.G ${ }^{1 *}$, Emilreyan. ${ }^{2}$, \\ ${ }^{1}$ Assistant Professor, Easwari Engineering College \\ 2 P.G student, Easwari Engineering College \\ *Corresponding author E-mail: prabhagandhi1985@gmail.com
}

\begin{abstract}
Economy, ease and speed of construction are the main factors for using steel as a building material. In this paper conventional hot rolled steel I-beam sections are considered as the main flexural member of industrial buildings. The main goal is to increase the load carrying capacity of the beam with inverted w shape stiffener condition at centre. The initiative was to identify the maximum load behaviour and deflection of steel beams with stiffener in the web. The performance of such beams has been considered only for vertical loads. Hot rolled steel beam of ISMB 100 with stiffener were tested to failure experimentally. The beams were simply supported at the ends and subjected to a 2 equal concentrated load applied at one third of span from both ends. The deflection at centre of beam and various failure patterns are studied. All the beams were analyzed by the finite element method by using general finite element analysis softw are ANSYS and the results were compared with those obtained experimentally. The finite element results for deformation and ultimate strength shows good agreement with the corresponding values observed in the experiments. At last, a comparative study was carried out using finite element method to examine that which type of beam gives best performance during loading. The numerical results indicate that the use of hot rolled I section with stiffener is an economical and advantageous choice.
\end{abstract}

Keywords: Horizontal and vertical stiffener, Rolled steel section, Inclined stiffener, Flexural strength, etc..

\section{Introduction}

Laterally stable steel beams can fail only by (a) flexure (b) shear (c) bearing, assuming the local buckling of slender components does not occur. These three conditions are the criteria for limit state design of steel beams. Steel beams would also become unserviceable due to excessive deflection and it is classified as a limit state of serviceability.the factored design moment $\mathrm{m}$ at any section, in a beam due to external actions shall satisfy

$$
\mathrm{M} \leq \mathrm{md}
$$

Where $\mathrm{md}=$ design bending strength of the section

Members subjected to predominant bending shall have adequate design strength to resist concentrated force, shear force and bending moment imposed upon and their combinations Further, the members shall satisfy the deflection limitation presented as serviceability criteria. Member subjected to other forces in addition to bending or biaxial bending shall be designed.The effective span of a beam shall be taken as the distance between the centre to centre of supports, except where the point of application of the reaction is taken as eccentric at the support. It shall be permissible

to take the effective span as the length between the assumed lines of the reactions.Lateral-torsional buckling is a limit-state of structural usefulness where the deformation of a beam changes from predominantly in-plane deflection to a combination of lateral deflection and twisting while the load capacity remains first constant, before dropping off due to large deflections. The analytical aspects of determining the lateral-torsional buckling strength are quite complex, and close form solutions exist only for the simplest cases.

\section{Objective}

(i)The effect of intermediate and inclined lateral stiffeners on load carrying capacity of simply supported hot rolled steel I-beam under various load combinations.

(ii) Load carrying capacity of beam, maximum deflection, stressstrain behavior, curvature behavior, maximum stresses in beam and stiffener have to be analyzed.

(iii) A series of beams modeled using 3d-finite element software like ansys is used to analyze the behavior of beam.

(iv) A theoretical design results, analytic results along with experimental results have been compared and final results are arrived.

\section{Stiffener Outline}

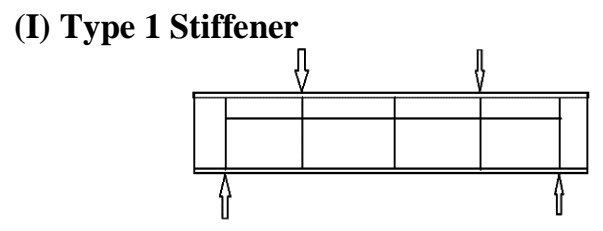


(Ii) Type 2 Stiffeners

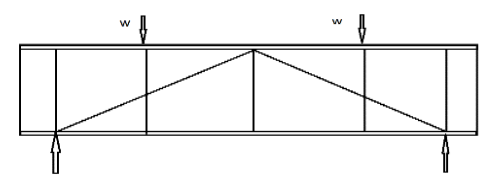

(iii) Type 3 stiffeners

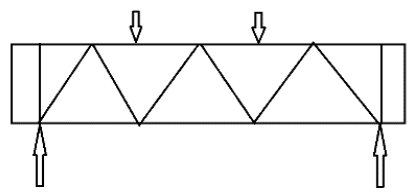

\section{Theoretical Report}

\begin{tabular}{|c|c|}
\hline Designation & Values \\
\hline code & Is800:2007 \\
\hline Section type & Girder beam \\
\hline Loading type & Udl \\
\hline Span & $20 \mathrm{~m}$ \\
\hline Dead load & $20 \mathrm{KN} / \mathrm{m}$ \\
\hline Live load & $250 \mathrm{KN} / \mathrm{m}$ \\
\hline Self weight & $18 \mathrm{KN} / \mathrm{m}$ \\
\hline Ultimate load & $432 \mathrm{KN} / \mathrm{m}$ \\
\hline Maximum BM & $21.6 \mathrm{E} 9 \mathrm{Nmm}$ \\
\hline Maximum SF & $4320 \mathrm{KN}$ \\
\hline Overall depth & $2500 \mathrm{~mm}$ \\
\hline Depth of web & $2400 \mathrm{~mm}$ \\
\hline Thickness of web & $12 \mathrm{~mm}$ \\
\hline Thickness of flange & $50 \mathrm{~mm}$ \\
\hline Breadth of flange & $500 \mathrm{~mm}$ \\
\hline Outstand of flange & $244 \mathrm{~mm}$ \\
\hline $\mathrm{B} / \mathrm{t}_{\mathrm{f}}$ & 4.88 \\
\hline Classification & Plastic \\
\hline Plastic section modulus & 78.53E6 cu.mm \\
\hline Designation & Values \\
\hline Elastic section modulus & 70.4E6 cu.mm \\
\hline Moment of inertia(elastic) & $88 \mathrm{E} 9 \mathrm{~mm}^{4}$ \\
\hline Plastic moment capacity & $27.85 \mathrm{E} 9 \mathrm{nmm}$ \\
\hline $\mathrm{d} / \mathrm{t}_{\mathrm{w}}$ & 206 \\
\hline Spacing of stiffener & $3000 \mathrm{~mm}$ \\
\hline $\mathrm{C} / \mathrm{d}$ & 1.25 \\
\hline $\mathrm{K}_{\mathrm{v}}$ & 11.6 \\
\hline Poisson ration & 0.3 \\
\hline Young modulus & $2 \mathrm{E} 5 \mathrm{MPa}$ \\
\hline Elastic critical shear stress & $52.42 \mathrm{MPa}$ \\
\hline Non dimensional slenderness ratio & 1.65 \\
\hline Shear stress(nominal) & $53.01 \mathrm{MPa}$ \\
\hline Critical force & $1526 \mathrm{KN}$ \\
\hline Margin of unsafety & $2794 \mathrm{KN}$ \\
\hline Designation & Values \\
\hline Limited moment of resistance & 4.09E9 Nmm \\
\hline Moment in tension field & 991.6E6 Nmm \\
\hline Force in tension field & $4.156 \mathrm{E} 6 \mathrm{~N}$ \\
\hline $\begin{array}{l}\text { Additional force due to moment in } \\
\text { tension field }\end{array}$ & $330 \mathrm{KN}$ \\
\hline Total design force & $4650 \mathrm{KN}$ \\
\hline Longitudinal shear & $2100 \mathrm{KN}$ \\
\hline $\begin{array}{l}\text { Design load on EBS(end bearing } \\
\text { stiffener) }\end{array}$ & $4650 \mathrm{KN}$ \\
\hline Breadth of stiffener & $200 \mathrm{~mm}$ \\
\hline Thickness of stiffener & $25 \mathrm{~mm}$ \\
\hline Area of stiffener & $10000 \mathrm{sq} \mathrm{mm}$ \\
\hline Web crippling & $340 \mathrm{KN}$ \\
\hline Load distribution & $1 \mathrm{~V}: 2.5 \mathrm{H}$ \\
\hline Total bearing strength & $4960 \mathrm{KN}$ \\
\hline Outstand condition & Within permissible limits \\
\hline Buckling area of EBS & $22880 \mathrm{sq} \mathrm{mm}$ \\
\hline
\end{tabular}

\begin{tabular}{|l|l|}
\hline MOI of axis level & $291.42 \mathrm{E} 6 \mathrm{~mm} 4$ \\
\hline Radius of gyration & $112.85 \mathrm{~mm}$ \\
\hline Slenderness ratio & 14.8 \\
\hline Designation & Values \\
\hline Buckling class & $\mathrm{C}$ \\
\hline Direct compression & $225.5 \mathrm{MPa}$ \\
\hline Compression load & $5159 \mathrm{KN}$ \\
\hline Design load on its & $3024 \mathrm{KN}$ \\
\hline Minimum MOI & $3.98 \mathrm{E} 6 \mathrm{~mm} 4$ \\
\hline Stiffener force due to external load & $2540 \mathrm{KN}$ \\
\hline Direct compression & $224.5 \mathrm{MPa}$ \\
\hline Compression load & $3538 \mathrm{KN}$ \\
\hline Minimum MOI & $20.76 \mathrm{E} 6 \mathrm{~mm} 4$ \\
\hline Stiffener requirements & Satisfied limit conditions as per \\
& code \\
\hline Connection ( EBS and web) & Provide 40mm weld @ 150mm c/c \\
\hline Connection (HS and web) & Provide 40mm weld @300mm c/c \\
\hline Deflection & $78.23 \mathrm{~mm}$ \\
\hline
\end{tabular}

\section{Experimental Report (1:20)}

\section{(I) Steel Beam without Stiffener}
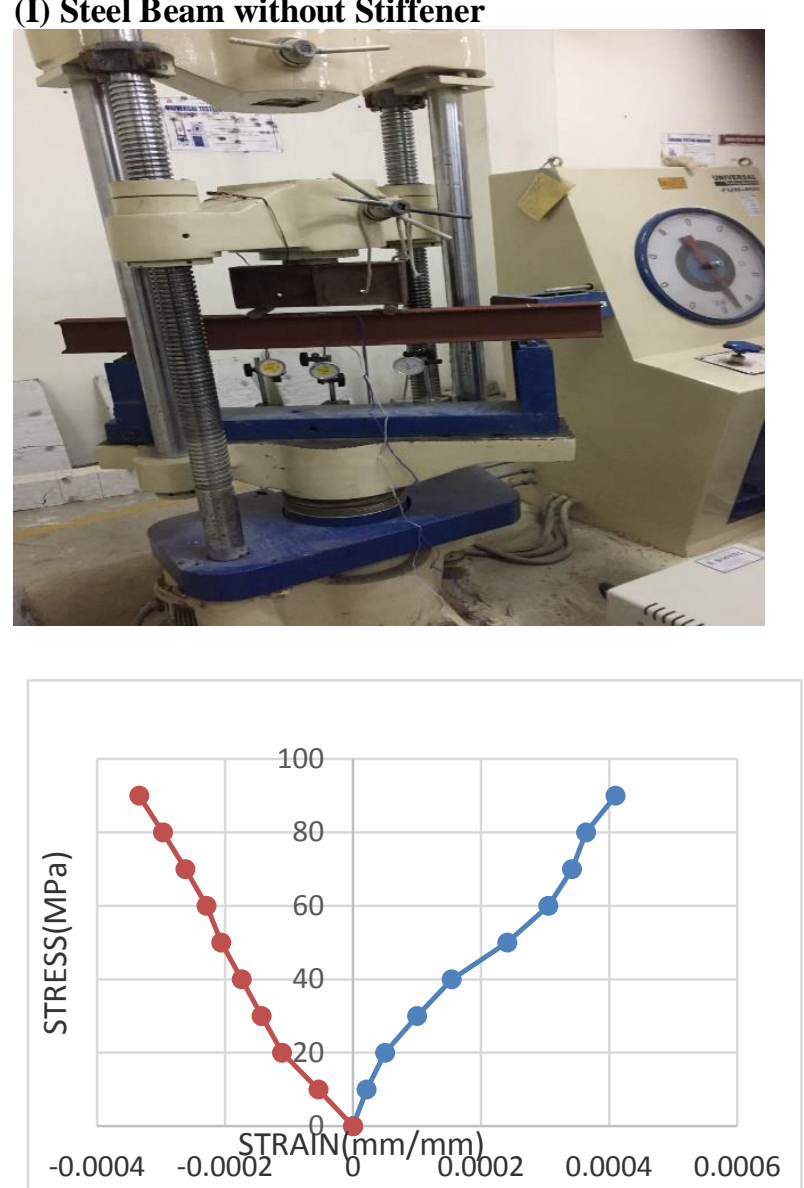

Fig 2 stress strain diagram of unstiffened beam 


\section{(Ii) Stiffener Beam 1}
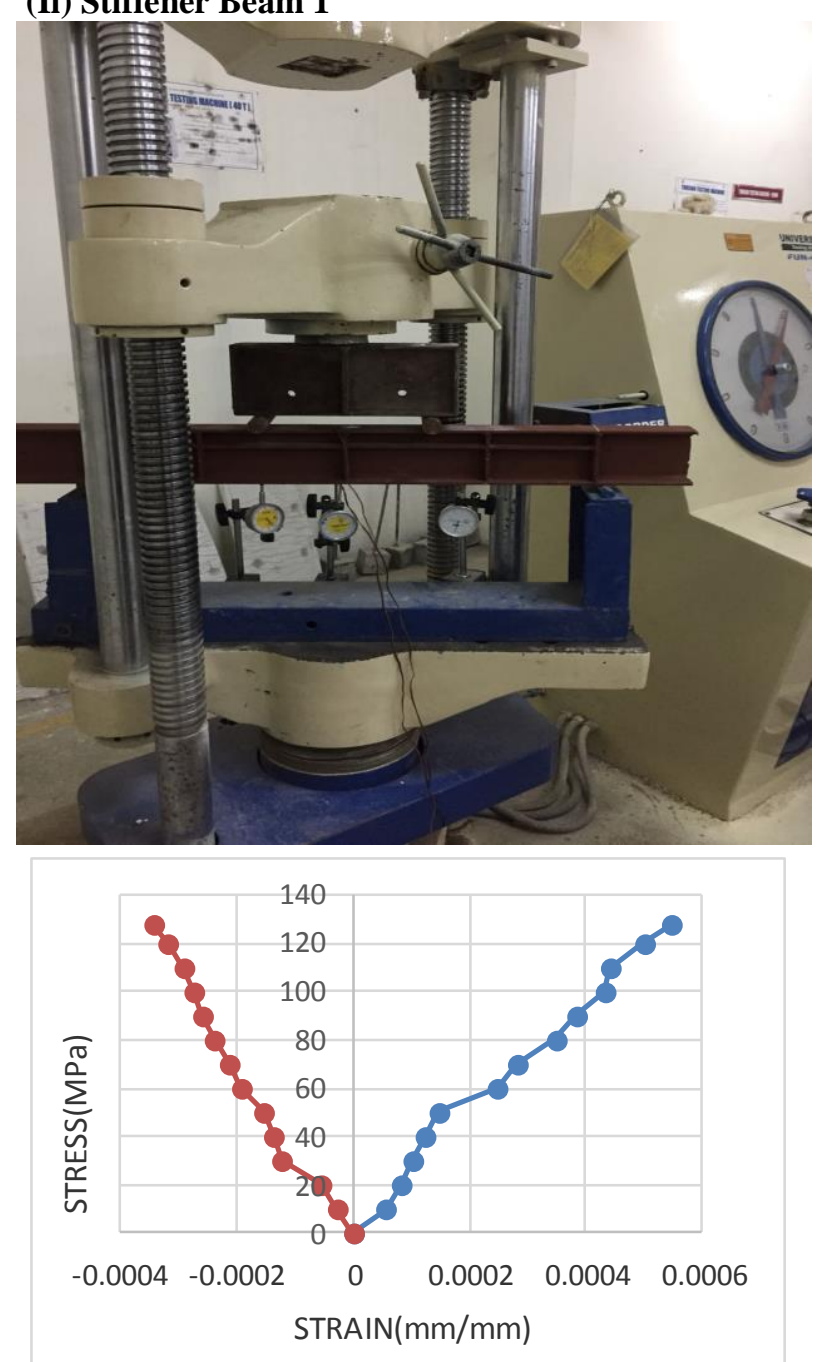

Fig 3 stress strain diagram for stiffened beam 1

\section{(Iii) Stiffened Beam 2}

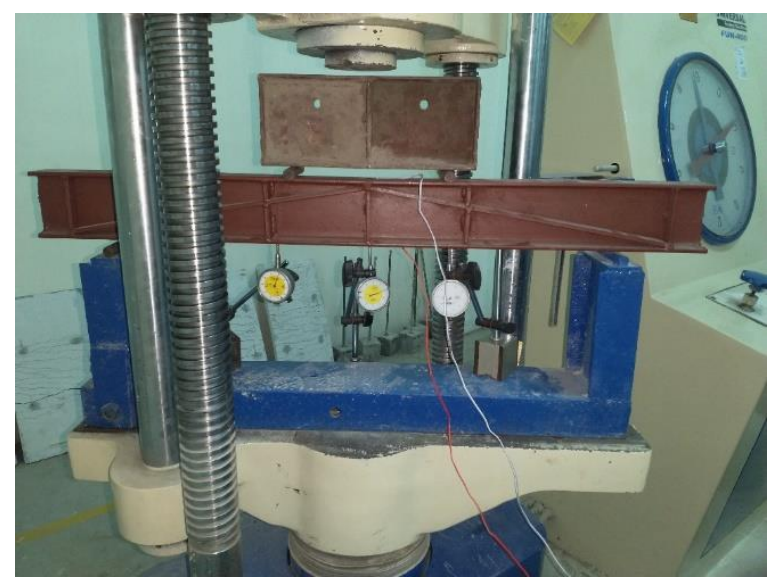

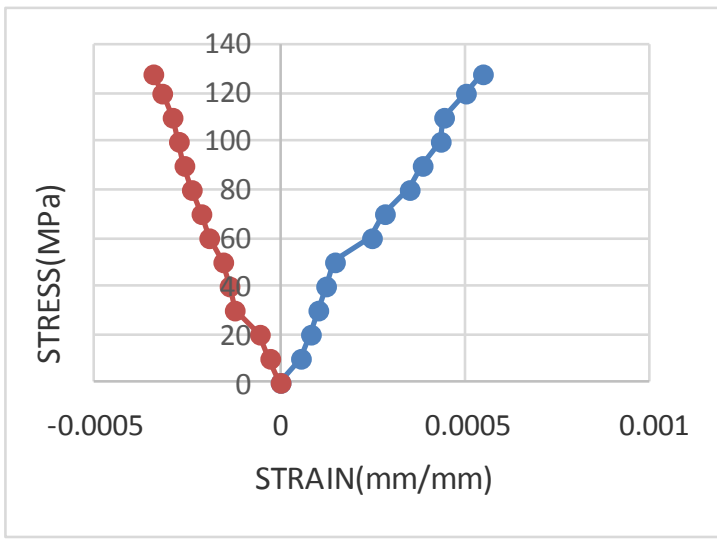

Fig 4 stress strain diagram for stiffened beam 2

\section{(Iv)Stiffener Beam 3}
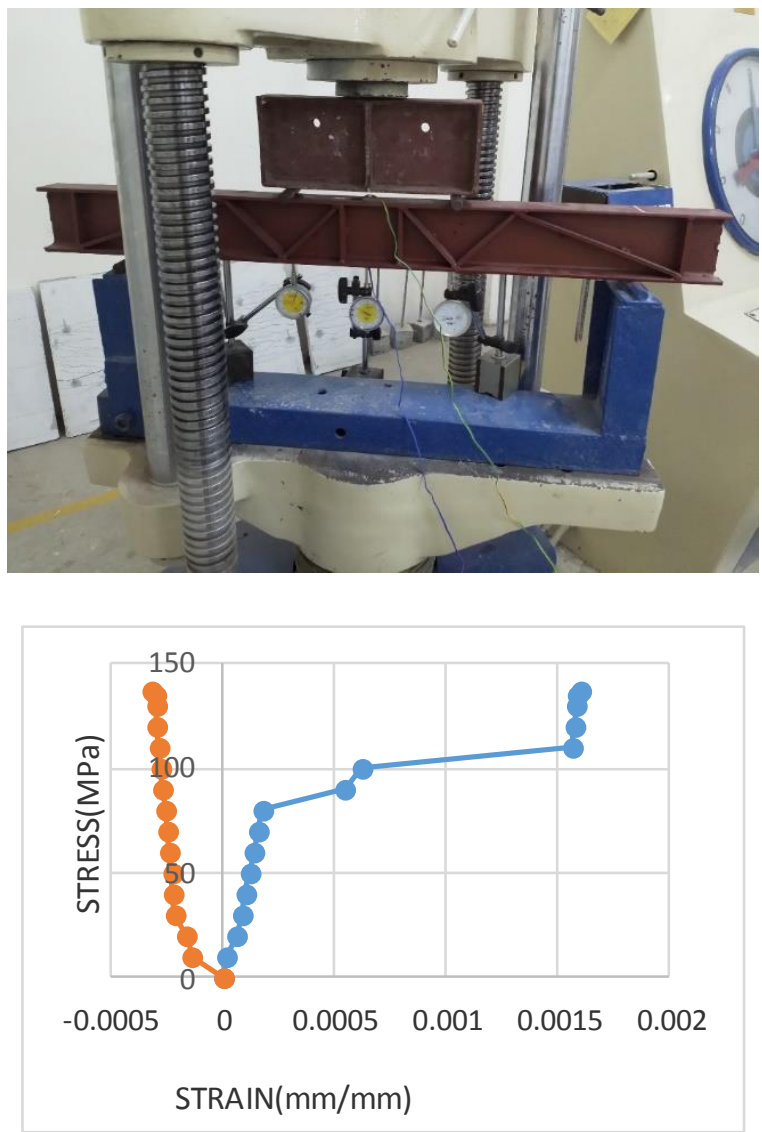

Fig 5 stress strain diagram for stiffened beam 3 


\section{(V) Deflection Comparison}

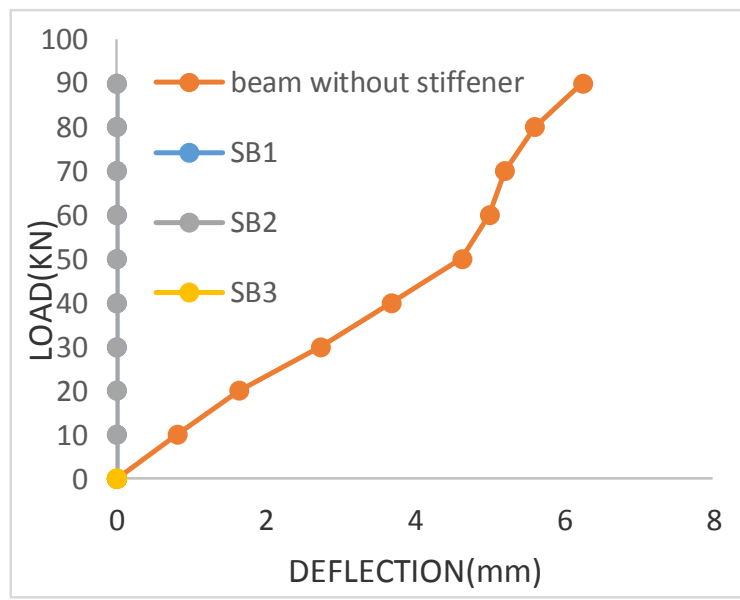

\section{Analytical Report}

\section{(i) Unstiffened Beam (Using STADDPRO)}

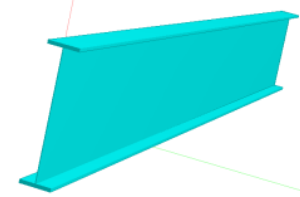

Fig 6 rendered view of unstiffened beam
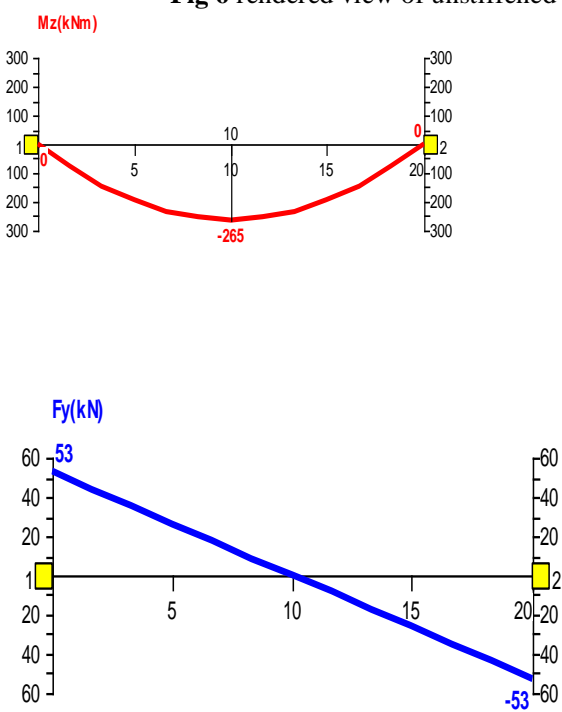

Fig 6: BM and SF diagram of unstiffened beam

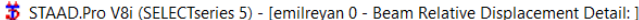

File Edit View Tools Select Results Report Mode Window Help

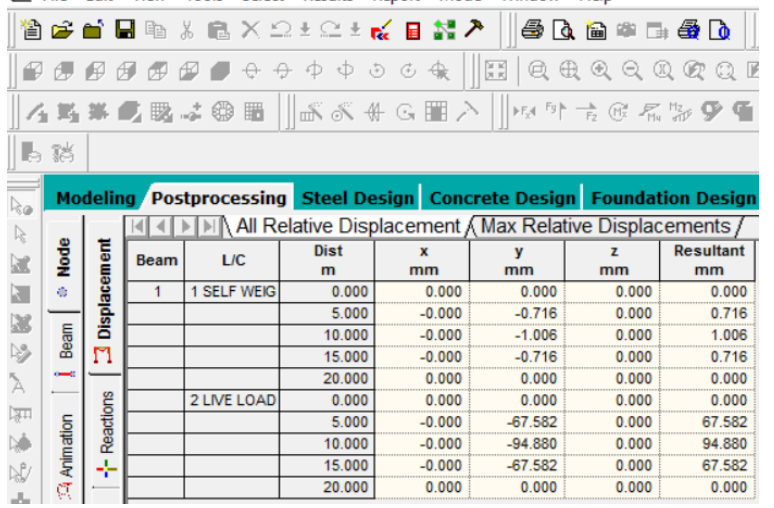

\section{(Ii) Stiffened Beams (ANSYS)}

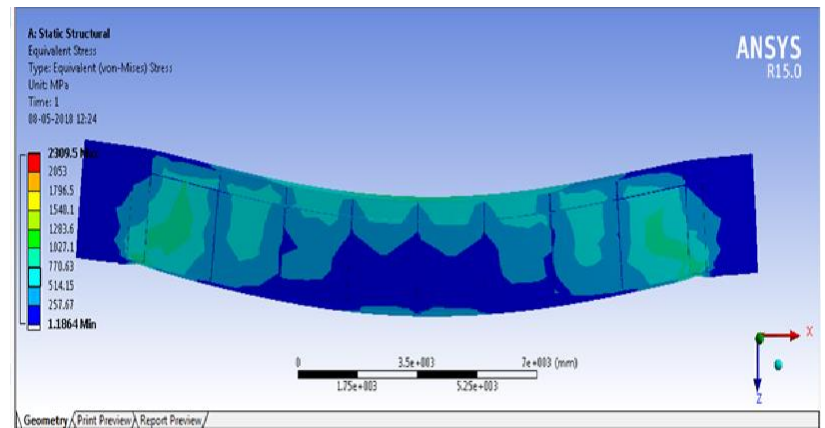

Fig 7 stress variation in stiffened beam

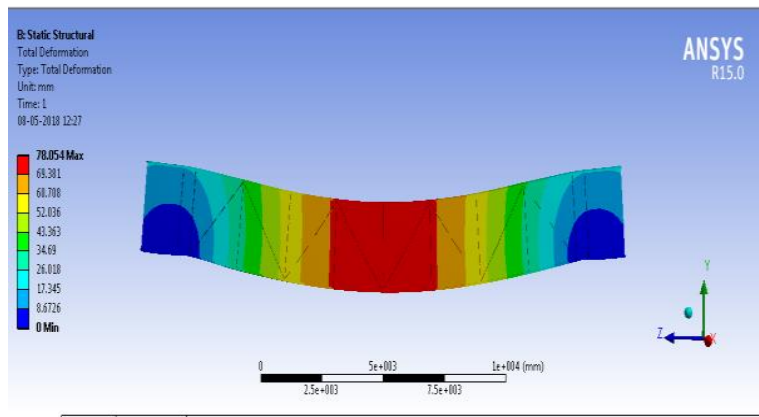

Fig 8 deflection in stiffened beam

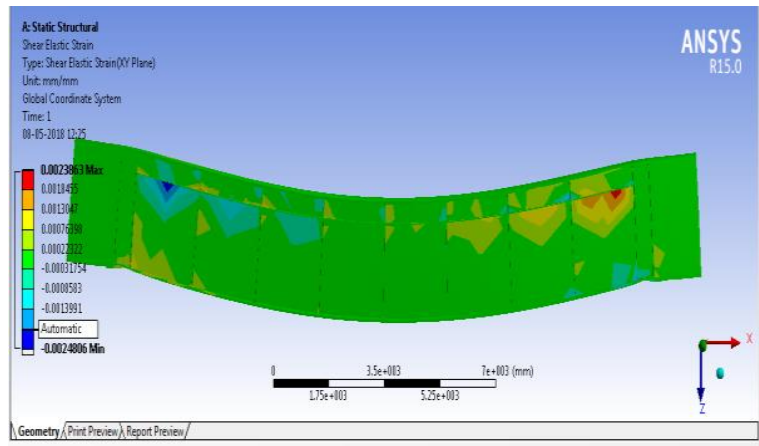

Fig 9 strain variation in stiffened beam

\section{Result and Discussion}

(i) Load carrying capacity of beam
(a) Without stiffener $=90 \mathrm{KN}$
(b) Type 1 stiffener $=102 \mathrm{KN}$
(c) Type 2 stiffener $=128 \mathrm{KN}$
(d) Type 3 stiffener $=137 \mathrm{KN}$

(ii) Comparative results 


\begin{tabular}{|l|l|l|l|l|}
\hline Stiffener position & AD & AS & ED & ES \\
& $(\mathrm{mm})$ & & $(\mathrm{mm})$ & \\
\hline Without stiffener & 94.88 & 0.00186 & 125 & 0.00041 \\
\hline Type 1 stiffener & 91.66 & 0.00191 & 85.66 & 0.00085 \\
\hline Type 2 stiffener & 85.26 & 0.00193 & 81.23 & 0.0012 \\
\hline Type 3 stiffener & 78.66 & 0.00203 & 76.25 & 0.0019 \\
\hline
\end{tabular}

\section{Note:}

Ad=analytic deflection

As=analytic strain

$\mathrm{Ed}=$ experimental deflection $(1: 20)$

$E s=e x p e r i m e n t a l$ strain $(1: 20)$

(iii) Estimation of material cost(as per field application)

(a) Beam with no stiffener

Volume of beam $=1.576$ cubic metre

Unit weight of steel $=7850 \mathrm{~kg} / \mathrm{cub} \mathrm{m}$

Weight of beam $=12371.6 \mathrm{~kg}$

Cost of steel per $\mathrm{kg}=\mathrm{rs} .60$

Total cost $=7.42$ lakhs

(b) Beam with type 1 stiffener

Volume of beam $=1.824$ cubic metre

Unit weight of steel $=7850 \mathrm{~kg} / \mathrm{cub} \mathrm{m}$

Weight of beam $=14318.4 \mathrm{~kg}$

Cost of steel per $\mathrm{kg}=\mathrm{rs} .60$

Total cost $=8.6$ lakh

(c) Beam with type 2 stiffener

Volume of beam $=1.856$ cubic metre

Unit weight of steel $=7850 \mathrm{~kg} / \mathrm{cub} \mathrm{m}$

Weight of beam $=14569.6 \mathrm{~kg}$

Cost of steel per kg $=$ rs.60

Total cost $=8.74$ lakh

(d) Beam with type 3 stiffener

Volume of beam $=1.923$ cubic metre

Unit weight of steel $=7850 \mathrm{~kg} / \mathrm{cub} \mathrm{m}$

Weight of beam $=15095.5 \mathrm{~kg}$

Cost of steel per kg $=$ rs. 60

Total cost $=9.5$ lakh

\section{Conclusion}

(i) The load carrying behaviour of type 3 stiffener beam is $20 \%$ higher than type 1 stiffener, $10 \%$ higher than type 2 stiffener and $41 \%$ higher than beam with no stiffener.

(ii) The deflection behaviour of type 3 stiffener beam is $5 \%$ higher than type 2 stiffener and 10\% higher than type 1 stiffener and 15\% higher than beam with no stiffener.

(iii) For higher strength purpose, type 3 stiffener beam is preferable but for both economical and strength purpose, type 2 stiffener beam is preferable.

(iv) The above results should be completely compared and concluded theoretically, analytically and experimentally (1:20).

\section{References}

[1] Dewolf tj, pekoz t, winter g. Local and overall buckling of coldformed members. Journal of structural engineering, asce, no. 10, 100(1974) 2017-36.

[2] Beshara b, lawson tj. Built-up girder screw connection variation flexural tests, dietrich design group internal report, april, 2002.

[3] Yu c, schafer bw, local buckling tests on cold-formed steel beams, journal of structural engineering, asce, 129(2003) 1596-606.

[4] Serrette rl, performance of edge-loaded cold formed steel built-up box beams, journal of structural engineering, asce, no. 3, 9(2004) $170-4$.

[5] Ren w, fang s, young b, finite-element simulation and design of cold-formed steel channels subjected to web crippling, journal of structural engineering, asce, no. 12, 132(2006) 1967-75.

[6] Akay, h.v., johnson c.p. And will k.m. (1977), lateral and local buckling of beams and frames, journal of structural engineering, asce, vol. 103, no. St9, sept., pp. 1821-1832.

[7] Avery p. (1994) lateral distortional buckling behaviour of hollow flange beams with web stiffeners, beng thesis, queensland university of technology, australia.

[8] Avery p. And mahendran, m. (1996), finite element analysis of hollow flange beams with web stiffeners, research report, queensland university of technology.

[9] Bradford, m.a. And trahair, n.s. (1981), distortional buckling of ibeams, journal of structural engineering, asce, vol. 107, no. St2, pp. 355-370.

[10] dempsey, r.i. (1991), hollow flange beams: the new alternative, technical presentation, aisc,june.

[11] dempsey r.i. (1990), structural behaviour and design of hollow flange beams, proc. Of the second national structural engineering conference

[12] Richard redwood and sevak demirdjian "castellated beam web buckling in shear" journal of structural engineering 1 october 1998/1207

[13] Redwood, r. \& demirdjian, s. (1998). Castellated beam web buckling in shear. Journal of structural engineering (asce), vol. 124, 10, pp. 1202-1207.

[14] Sweedan m. I. (2011). Elastic lateral stability of i-shaped cellular steel beams. Journal of constructional steel research, vol. 67, no. 2, pp. 151-163.

[15] Konstantinos, t. D. \& mello, c. (2011). Web buckling study of the behavior and strength of perforated steel beam with different novel web opening shapes. Journal of constructional steel research, vol. 67, pp. 1605- 16206

[16] Luis laim, joao paulo c rodrigues, luis s silva, "flexural behaviour of cold formed steel beams", dfe 2013-international conference on design, fabrication and economy of metal structures, (isbn: 978-3642-36690-19), hungary

[17] Jia-hui zhang, ben young, "compression test of cold- formed steel ishaped open sections with edge and web stiffeners", thinwalled structures 52 (2012) 1-11

[18] Rajesh kumar b, anil kumar patidar and helen santhi. M, "finite element analysis of concrete filled cold formed steel sections using ansys", ijace, vol no: 1, 2013, pp. 11-18

[19] Sudha.k , sukumar.s, behaviour of cold-formed steel builtup i section under bending, international journal of engineering and technology (ijet) vol no: 5, 2013 pp 4622-4631

[20] IS 800-2007 code of practice for general construction in steel. 